\title{
A REVIEW: DEVELOPING CHARACTER STUDENTS TROUGH SPOT CAPTURING METHOD IN SCIENCE EDUCATION LEARNING
}

\author{
${ }^{1}$ Kiki Septaria \\ 1Department of Science Education, Faculty of Teacher Training and Education, Lamongan \\ Islamic University. Jl. Veteran No.53A Lamongan, Indonesia \\ Email:kikiseptaria@unisla.ac.id
}

\section{Article History}

Received: 22 January

Revised: 20 February

Published: March 2019

\begin{abstract}
Characters is something that shows how good someone is. Every human being has the characters since they birth. Characters can be developed on a macro or micro basis, one of which is micro ways with learning and teaching activity in schools. Selection method of learning is vey important to develop good character in students. One method student-centered learning is the Spot Capturing method. This research method uses a literature study method that wants to know the characters that can be developed using the Spot capturing method. The literature results show that spot capturing methods can develop several characters in their implementation such as curiosity, honesty, discipline, hard work, creative, responsibility, social care and communicative.
\end{abstract}

Keywords: Characters, Spot Capturing, Micro.

How to cite: Septaria, Kiki. (2019). A REVIEW: DEVELOPING CHARACTER STUDENTS TROUGH SPOT CAPTURING METHOD IN SCIENCE EDUCATION LEARNING. Science Education and Application Journal (SEAJ). Vol. 1 No.1: 39 - 45.

\section{INTRODUCTION}

The modernization and globalization of the $21^{\text {st }}$ century the current ease in obtaining human activity needs. Various Affairs in the who needs ranging from education, food needs until the information in seconds is able to be accessed and disseminated to the public. Ease in all seesuatu that can be accessed via a mobile phone or a computer, it has positive and negative sides which need to be considered and improved. One example, namely the lack of socializing with the public at large and easy to believe in the information that is accessed via a mobile phone or a computer without a trace source is accurate so that it will grow and form personal chars not either. Character in public life is more often defined as personalities from someone. Personality can be defined as the hallmark of someone who looks from the attitude or behaviour of a person is shown. The characteristic of a person it is a trait that is formed from observation, adaptation, as well as creations that exist from birth, or also received someone from the surrounding environment within a specified time, could be from family and school.

The character is the behavior and attitude of life owned by someone (Fu'adi, 2016). The characters grow and formed it is important early on who will be mentored trained so that characters that owned one becomes a positive character and capable as the successor of the nation towards the better. The importance of guiding and educating character early on was a weak mental and moral awareness, and lack of moral education in the family and society. When the characters are not positive social interactions and the negative character is higher then the moral degradation will occur, behavior and delinquency in particular juvenile delinquency. Education that operates science and character have different levels or level either in age or in secondary school. This level is the level or levels that would continue to be experienced for learning well in school following the formal and non-formal. Secondary characters include education that operates the formation of character should occur at an early age in the family, at 
the age of teens already aims to develop characters that are owned by a person, as well as on age of consent operates on the establishment of a person's character (Kristiawan, 2015).

Juvenile delinquency is currently an issue which still often discussed and still keep developing according guidelines situation, environment, globalization and the modernization of every aspect of social life. Teenage is the period in which the phase of the conflict (conflict) either by themselves or with adults. This adolescent phase generally begins at the age of 11 to 15 years who have formal operational thought patterns where a teenager was able to think logically for various types of problems that faced and able to accept with good point of view nor the the opinions of others (Zahrotul, Firdaus. 2013). At the age of adolescence this is someone still in formal education at junior high school level (Junior High School). Seen in terms of biological, adolescent phase (formal operational) it is puberty which is physically, cognitively, development of social and moral reasoning develops rapidly and needed guidance from adults to develop character positive start to form.

Juvenile delinquency is very diverse, however many communities who feel the degradation or decrease social character which is very extreme. One example of the decline of social character is the behavior of bullying or pembulian lively took place in the school environment (Permata Sari, 2017). When someone does the behavior of pembulian is the result caused by the supportive environment such as the community apathy or ignore the activities or Affairs of the others, has experienced a pembulian or as a victim and to get a sense of the neighborhood safe and comfortable place to stay (Permata Sari, 2017).

The Government of Indonesia was aware of the importance of positive character that must be owned by someone and had to be established and led early on. Krisisi characters that occur can be seen in the perspective or the perspective of nomotesis and ideografis. Nomotesis is the point of view of the character of the nation or its citizens are sourced from Pancasila. This is very important because of Pancasila will make basic character, attitude, commitment, point of view, the pattern of competence or ability and thinks can be done by someone. Ideological point of view is a point of view which refers to the ability of a person who is productive or creative, and produce something that is produced by a person.

The Ministry of education and culture and the Ministry of research and Technology Colleges aware of the importance of character education at early stages so that the formation of positive character on generaasi gold year 2045 or Indonesia after Indonesia became independent during the 100 of the year. These two ministries collaborate to support any institutions of both formal and non-formal education to put forward a balanced academic and character. Concern the Government is tercantung in Act No. 20 of the year 2003 which describes the importance of shaping the character that must be facilitated through national education. It is clear that the education system in Indonesia range from elementary school to College not only educate scientific and professional in person but should also form a positive character that is attached to a person because the education is a major Foundation or basis to improve the quality of human resources in order for a country in a country not lose competitiveness with quality human resources from other countries.

The more obvious attention again delivered by IR. Joko Widodo which clearly and unequivocally lays out the concept of a mental revolution for the entire community of Indonesia. Mental revolution is one of the changes in Indonesia which has the human being embodies the personality of the result that start from education (Kristiawan, 2015). Starting from education because education environment is an environment that focuses on good habits are indeed made to conducive, comfortable, and make every student to absorb all the information and offer it as a science that will used at a later date (Information Bureau and the Council, 2014).

Education focuses to improve one's character is currently being talked about by the public, education of this kind is called character education. Character education is an activity in a system that seeks to instill moral values to the learners through the activities and 
conditioned in everyday life. Character education is not actually only recently developed in Indonesia, but education is already developed in the time of Ki Hajar Dewantara which described education as the efforts made by someone so reasonable manners, patterns think/thought of someone, and the development of a person's body can grow to a maximum.

Character education plan developed by the Ministry of national education by doing development in micro and macro or wide or narrow is defined can be developed in a learning, school or regional area (Kemendiknas, 2010). Development of character education in the macro can be done through three phases namely stages of planning, implementation and evaluation stages of the phase or review. A brief explanation of the stages of the development of the characters in a macro as follows:

1. Planning stage

In this planning phase is the process of extracting the data, the analysis of various data sources and of course focuses on philosophical considerations from religion, Pancasila and the 1945 Constitution also defined by relevant reori such behavior, brain development in accordance with age, as well as direct experiences of practitioners.

2. Implementation stage

At this stage of implementation highlights to experience in a teaching and learning process that would later end up on shaping one's character. The process of implementation of character education in schools well educated could this formal, non-formal and informal learning experiences will focus by way of interventions i.e. by way of designing learning composed so that it reaches its final destination that is the characters. Next up is the process of experiential learning by habituation in which someone in its environment will be created the situation and specific conditions that would make someone will get used to it or get used to matching characters that are conditioned.

3. Evaluation or review Stages

At this stage of the review is the assessment or assessment stage is to find out the character as well as evaluate the improvement in terms of character education in any indicator character education to be improved and enhanced in order for character education can be implanted to a person.

On the plan of character education in micro by Kemendiknas can be run through some process, namely:

1. The 4 pillars of character education that includes teaching and learning activities in the classroom, everyday there are cultural activities at school, the activities of ko-curricular and extra kulikuler activities as well as activities conducted conducted a day a good day in the home and in the surrounding environment.

2. Character education at a time when teaching and learning activities can be done via the method of integration of each subject in all schools. The impact of the integration of character Education these subjects may be the impact can be felt instantly occurred as well as the impact that takes long enough so that certain characters can be embedded in one's self.

3. Character education at school or a particular Education Unit can be done by facilitating both physically and habits that are regulated in the rules of the school to build characters that will be implanted to someone.

Character education at home or with family and in the surrounding environment could be initiated in the family interacting on a daily basis, parents have to give examples of positive character which will be implanted and provide reinforcement against characters such. So when someone from the family members studying in certain Education units then these people will be doing with the ability be positive character who had done every day at home. This is a chart of the character Education strategic plan which can be carried out by means of micro against someone who demonstrated by chart 1 (Ministry of people's Welfare Coordinator RI, 2010): 


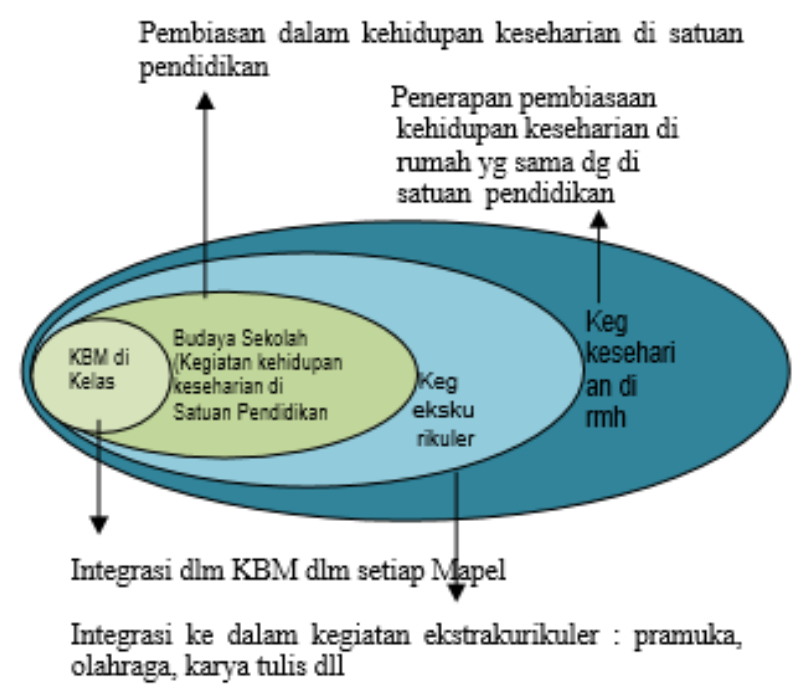

Figure 1. The integration of character education at the macro and micro plan (Zahrotul, Firdaus. 2013)

A character education in schools can be developed and guided by someone who organize and accommodate the formation of his character. The characters were developed by the Ministry of national education, among others (The development and Education of culture and character of the nation, the school Guidelines: 2010):

1) Religious

2) Honest

3) Tolerance,

4) Discipline,

5) Hard work,

6) Creative,

7) Independent,

8) Democratic,

9) Curiosity,

10) Spirit of nationality,

11) Love of the fatherland,

12) Appreciate your achievements,

13) Friendly/Communicative,

14) Peace-loving,

15) An avid reader

16) Care for the environment,

17) Social Care, and

18) Responsibility

Any points or characters that will be developed through several phases i.e. first phase is the knowledge about the characters and each character would be developed, the second stage is the implementation that is exemplified by the more adult or already have a character that will be developed and the last stage is the stage of conditioning is done in an environment especially the school environment.

Conditioning in the school begins with the interaction between teacher and pupil as teacher as the object to be developed his character. This interaction can be carried out in accordance with the implementation plan and the learning that has been prepared for teachers in each subject including Science subjects (IPA). Therefore, a teacher has a very important role in developing the character of students because students will have good character when taught, exemplified and conditioned by a teacher. 
On the subjects of Natural Science lesson plans will be adjusted, with the material or topic being taught and the characteristics of their students in the classroom. The selection of model planning of learning will be crucial so that the material can be accepted and stored in long-term memory by way of focusing the students who perform activities and teacher guides, only able to develop the character of the good students, as well as make learning the IPA be meaningful for students. One of the suitable learning methods are used in the learning material or topic IPA is a method of Spot Capturing.

Spot Capturing method is one method of learning that can facilitate or assist students with a variety of ways/different learning methods. Of course, each student is made possible to have a different learning style, suppose there is A student that is easier to understand when doing the movements with the stair, another student of B that is easy to learn something by listening to other students as well as anytime that it is possible to have a different learning style. Thus, the researchers want to find literature which are capable of Spot Capturing learning to develop the character of a good student during the learning takes place.

\section{RESEARCH METHOD}

Research methods used in the research and writing of this article was a literature study method where researchers seek a variety of reference source such as a book, start a journal of research, scientific articles or references that are relevant to the topic at the discussion Spot Capturing that can build the character of students. Method study of literature can be used as a guide in developing a core of matter or topic of discussion on an appropriate concept topic covered. The writing of this article is in compliance with the procedures of studies library where all ideas, information and ideas are analyzed, which are then made into one unit and developed thoroughly.

\section{RESULTS AND DISCUSSION}

Spot Capturing method is one method of learning that is capable of providing stimulus in the form of visuals, audio and touch to the students or learners, so students will better understand the material presented rather than just described or memorized only (Widiasmadi, 2010). This is because the method of Spot Capturing can facilitate a variety of learning styles, namely the visual, auditory learning style, reading and kinesthetic, which all fit into several stages of implementation on a study using the method of Capturing (Spot Astuti, 2016).

The Spot Capturing method has several stages, animation / visualization / film, modeling / Viewer, creative games, creative assignments and tests-creative logic. This stage should match the sequence that has been set, although different portion/large number of delivery time. The first stage, namely the animation /visualization where students will be given an impression in the form of a picture or video to unearth the knowledge beginning students as well as increasing curiosity about natural phenomena that are on show since in learning IPA the result analysis of the natural phenomena that occur in everyday life - day. Curiosity is an attitude of results from a stimulus or stimulus given to find out in more depth and breadth than the intended object (Sobri: 2016). At this stage also can develop the characters care for the environment that is an action or attitude that aims to prevent and find solutions to natural damage from being studied (Sobri: 2016). Therefore, at this stage it is very important to draw attention to the students and also a solution in search of a natural phenomenon in particular environmental damage occurs because learning the Natural Science and the true environment of mutual relations (Taufiq: 2014).

The second stage is the viewer or modeling where students perform using props and touch it directly. At a time when learners do model use props, they will be given responsibility, learn mendiri and creative in solving when during the modeling and the result is not in 
accordance with the wish. Character of responsibility is an action of someone after being given specific tasks which are given responsibility will carry out the duties and obligations (Sobri: 2016). In addition, at this stage developed a standalone character where one does not depend on others and looking for an alternative to naturally mecari way or new ideas in solving permasalahanya (Budiyanto: 2014).

At the third stage is games or game creative. At this stage the students will be divided either in groups or individually and given certain users that must be resolved by the way respectively. Each student has different ways made possible in completing the game from a phenomenon that is studied. Characters of creative thinking is very important because later developed the learners will experience a variety of problems that must be solved (Siswono: 2005). In addition to the creative character, character to be honest with what was said and done it will be a very important role and character of the responsibility of what has been done during the search for a solution of the problem (Sobri: 2016). In addition, in this creative game if done in groups of characters that can be developed is a caring and communicative environment which is an act committed by a person to look for ways to prevent and resolve the problem environment together - the same and pass on to others (Astuti: 2016).

The fourth stage i.e. creative Assignments where students will be given a task and asked to find a way to resolve problems is given. This task will develop the creative character of having to find a way - a way that allows to resolve any problems and possible learners have a way - a different way. In addition to the creative character, the character of responsibility and hard work in trying to find the best way and convey how who've found in public is the most important thing. The fifth stage is a logical creative test where students will be given a logical question - question and asked to search for creative solutions. This is a test of cognitive tests done by the students, where students are exposed to problems that must be resolved. On the cognitive domain of learning, using a method of Capturing Spot will be known to a high increase in the results of his studies (Astuti: 2016). All stages in the method of Capturing, Spot the activity of Shiva during Capturing Spot learning implemented in each stage and the characters it is possible to be developed can be seen in table 1 below:

Table 1. The integration of the learning method of Capturing Spot elements in learning and development of students ' character

\begin{tabular}{|c|c|c|}
\hline $\begin{array}{c}\text { Stage Spot Capturing } \\
\text { Method }\end{array}$ & The Activity of Students & Characters Evolved \\
\hline $\begin{array}{l}\text { Animation /film } \\
\text { /visualization }\end{array}$ & $\begin{array}{l}\text { Students view and listen to video or } \\
\text { animation provided by teachers }\end{array}$ & $\begin{array}{l}\text { 1. Curiosity } \\
\text { 2. Care for the environment }\end{array}$ \\
\hline Modeling & $\begin{array}{l}\text { Student demonstrator trying to find } \\
\text { facts using props }\end{array}$ & $\begin{array}{l}\text { 1. Responsibility } \\
\text { 2. Self help } \\
\text { 3. Creative }\end{array}$ \\
\hline Creative gaming & $\begin{array}{l}\text { Students in groups and conduct joint } \\
\text { activities are guided by teachers }\end{array}$ & $\begin{array}{ll}\text { 1. } & \text { Creative } \\
\text { 2. } & \text { Honest } \\
\text { 3. } & \text { Responsibility } \\
\text { 4. } & \text { Social Care } \\
\text { 5. } & \text { Communicative }\end{array}$ \\
\hline $\begin{array}{l}\text { Creative Students } \\
\text { working }\end{array}$ & $\begin{array}{l}\text { Students working on a task assignment } \\
\text { to sharpen his creativity }\end{array}$ & $\begin{array}{ll}\text { 1. } & \text { Creativity } \\
\text { 2. } & \text { Responsibility } \\
\text { 3. } & \text { Hard work } \\
\text { 4. } & \text { Communicative }\end{array}$ \\
\hline Test logic-creative & $\begin{array}{l}\text { Students are given questions should be } \\
\text { answered with appropriate logic and } \\
\text { creatively to solve problems that } \\
\text { provided }\end{array}$ & $\begin{array}{ll}\text { 1. } & \text { Honest } \\
\text { 2. } & \text { Discipline } \\
\text { 3. } & \text { Responsibility }\end{array}$ \\
\hline
\end{tabular}


Study using the method of Capturing Spot is one of a student-centered learning method (centered on students). It can be seen from the activity during learning activity dominated by learners and teachers only as a facilitator or guide activities. At the time of the student-centered learning, then about the absorption material that made the topic of learning of the phenomenon a day - day will be longer in Save as one of knowledge were students respectively.

\section{CONCLUSION}

School environment is most effective in developing positive character inside each human being. This is because characters can be formed in a teaching and learning activities. Teaching and learning activities in schools vary widely where elections crucial highly influential learning methods. One of the methods of learning that can develop character, discipline, honest hard work, curiosity, creative, caring, responsibility, social and communicative learning methods is Capturing Spot. Character - the character who wants to be terfasilitasi in the developed stage - stage in Capturing Spot method i.e. the stage of animation / modeling / visualization, stage props, stage of the game (the game) creative, creative task phase and stage of creative logic.

\section{REFERENCES}

[1] Astuti, Siti Nur. Peningkatan hasil belajar siswa melalui metode Spot Capturing pada materi perpindahan kalor di SMAN Campurdarat. 2016. Surabaya: UNESA Press

[2] Widiasmadi, Nugroho. Spot Capturing. 2010. Yogyakarta: Indonesia Tera.

[3] Afifah, Siti. Implementasi Model Belajar Spot Capturing Dalam Meningkatkan Sikap Ekspresif Siswa Kelas II Tahun Pelajaran 2015/2016 Pada Pembelajaran PAI di SD 4 Adiwarno Hadiwarno Mejobo Kudus. Undergraduate thesis, Stain Kudus.

[4] Ariesta, Freedy Widya, dkk. Development of Spot Capturing Problem Based Models for Growing Elementary School Students' Character. 2017. Bina Nusantara University Indonesia.

[5] Sobri, Ahmad Yusuf. Menumbuhkan Nilai Karakter Siswa Di Sekolah. 2015. Universitas Negeri Malang.

[6] Taufiq, M. Pengembangan Media Pembelajaran IPA Terpadu Berkarakter Peduli Lingkungan Tema "Konservasi" Berpendekatan Science-Edutainment. 2014. Universitas Negeri Semarang.

[7] Sigiyono. 2015. Metode Penelitian Pendidikan (Pendekatan Kuantitatif, Kualitatif, dan R\&D). Bandung: Alfabeta.

[8] Borich, Gary D.1994. Observation Skill for Effective Teaching. New York: Mac Millian Publishing Company

[9] Trianto. (2010). Model Pembelajaran Terpadu. Jakarta: Bumi Aksara. 